\title{
Effect of Plant Essential Oils on Ralstonia solanacearum Race 4 and Bacterial Wilt of Edible Ginger
}

Mathews L. Paret, Department of Plant and Environmental Protection Sciences (PEPS), University of Hawaii at Manoa, Honolulu 96822; Roxana Cabos, United States Department of Agriculture, Agricultural Research Service, Pacific Basin Agricultural Research Center, Hilo, HI 96720; B. A. Kratky, Department of Tropical Plant and Soil Sciences, University of Hawaii at Manoa; and Anne M. Alvarez, PEPS, University of Hawaii at Manoa

\begin{abstract}
Paret, M. L., Cabos, R., Kratky, B. A., and Alvarez, A. M. 2010. Effect of plant essential oils on Ralstonia solanacearum race 4 and bacterial wilt of edible ginger. Plant Dis. 94:521-527.

Palmarosa (Cymbopogon martini), lemongrass (C. citratus), and eucalyptus (Eucalyptus globulus) oils were investigated for their effects on Ralstonia solanacearum race 4 and their potential use as biofumigants for reducing bacterial wilt disease of edible ginger (Zingiber officinale). Three concentrations of the oils $(0.04,0.07$, and $0.14 \% \mathrm{vol} / \mathrm{vol})$ were evaluated by culture amendment assays, epifluorescence microscopy, and studies in potting medium. In culture amendment assays with palmarosa and lemongrass oils at $0.04 \%$, both oils significantly reduced the growth of the bacterium compared with the control, and at 0.07 and $0.14 \%$ they showed complete inhibition of bacterial growth. Epifluorescence microscopic observations showed cell deterioration in 95 to $100 \%$ of the cells at all concentrations of palmarosa and lemongrass oils, indicating its bactericidal properties. Eucalyptus oil treatments at 0.04 and $0.07 \%$ had bacteriostatic effects on the cells. The pathogen was not detected in $R$. solanacearum-infested potting medium after treatment with palmarosa and lemongrass oils at 0.07 and $0.14 \%$ in any of the experiments. Bacterial wilt incidence on edible ginger was significantly reduced when planted in essential oil-treated potting medium. None of the essential oil treatments reduced the growth or yield of edible ginger grown for 180 days in 5-liter pots.
\end{abstract}

Bacterial wilt is a major constraint for production of edible ginger (Zingiber officinale R.) in many tropical and subtropical regions of the world including Hawaii $(1,25)$. The disease is caused by the soilborne bacterial pathogen Ralstonia solanacearum race 4 , which has caused major economic losses to the edible ginger industry. $R$. solanacearum is thought to have entered the isolated tropical ecosystem of Hawaii through the import of latently infected planting material. Once fields became infested with the pathogen, they were unsuitable for cultivation of edible ginger because the inoculum persisted on plant debris, weeds, and farm equipment (23). The disease is currently widespread in all ginger-growing areas on the island of Hawaii $(7,23)$.

The key problems in bacterial wilt management have been the unavailability of healthy planting material, pathogen-free fields, and effective bactericidal com-

Corresponding author: A. M. Alvarez

E-mail: alvarez@hawaii.edu

Current address of M. L. Paret: North Florida Research and Education Center, University of Florida, Quincy 32351.

Accepted for publication 4 January 2010.

doi:10.1094/PDIS-94-5-0521

(C) 2010 The American Phytopathological Society pounds (6). In Hawaii, the first problem has been solved through efficient production of large amounts of bacterial wilt-free certified ginger rhizomes in bag culture from triple-indexed tissue cultured ginger (7). The second problem is the limited number of pathogen-free fields for cultivation. After the bacterial wilt disease started to cause major losses in production, ginger growers moved to fields not previously planted with edible ginger, and this led to the expansion of the $R$. solanacearuminfested areas (23). The third problem is the lack of effective chemical treatments for disinfecting $R$. solanacearum-infested fields. For decades, the broad-spectrum fumigant methyl bromide was successfully used in combination with chloropicrin for treating fields to reduce $R$. solanacearum and nematode populations $(8,22)$. However, based on the Montreal Protocol (21), use of methyl bromide is currently restricted by the U.S. Environmental Protection Agency. Thus, there is an immediate need for identifying suitable alternative bactericidal compounds that can be used for managing $R$. solanacearum by direct field application.

The use of plant essential oils as biofumigants as an alternative approach to management of bacterial wilt disease has been examined as a component in integrated disease management systems (10). Antimicrobial activity of numerous plant essential oils and their volatile components on plant pathogenic bacteria, fungi, nematodes, and viruses has been extensively investigated $(3,9-11,13,17,20)$ and has shown promising results. Previous studies on tomato have shown that essential oils of palmarosa and lemongrass at 0.04 and $0.07 \% \mathrm{vol} / \mathrm{vol}$ reduced populations of a highly pathogenic $R$. solanacearum race 1 strain (18) in potting medium studies. However, there are no previous studies on the effect of plant essential oils on the $R$. solanacearum race 4 strains, which cause bacterial wilt of edible ginger in tropical areas.

The objectives of the current study were to investigate the bactericidal and bacteriostatic effects of essential oils of palmarosa, lemongrass, and eucalyptus on a $R$. solanacearum race 4 strain; to develop an efficient method of treatment application in $R$. solanacearum race 4 -infested potting medium; and to determine the effects of the essential oils on the growth and yield of edible ginger.

\section{MATERIALS AND METHODS}

Bacterial strain used. A wellcharacterized strain of $R$. solanacearum race 4, A4515 (25), isolated from edible ginger from the island of Hawaii was used for the study. The strain is representative of a larger population (55 strains tested) and wilts plants within 5 to 7 days when steminoculated $\left(10^{8} \mathrm{CFU} / \mathrm{ml}\right)$ into 3 - to 5month-old edible ginger plants.

Plant essential oils. Essential oils of palmarosa, lemongrass, and eucalyptus (Camden-Grey Essential Oils, Inc., Doral, FL) were used for the current study. Three concentrations of the oils $(0.04,0.07$, and $0.14 \% \mathrm{vol} / \mathrm{vol}$ ) were tested based on results of a previous study on a $R$. solanacearum race 1 strain, which showed efficacy at 0.04 and $0.07 \%$ (18).

In vitro: Culture amendment assay. Plant essential oils tested were emulsified in Tween 20 (1:1 ratio) to enhance solubility of the oils. Twenty milliliters of liquid modified SMSA medium (4) were amended with $8 \mu$ of the oil to give a final concentration of $0.04 \% \mathrm{vol} / \mathrm{vol}$. Similarly, 14 and $28 \mu \mathrm{l}$ of the oils were emulsified and added to $20 \mathrm{ml}$ of medium for final concentrations of 0.07 and $0.14 \% \mathrm{vol} / \mathrm{vol}$, respectively. The medium was poured into each petri plate and dried in a circulating laminar flow hood for $20 \mathrm{~min}$. One millili- 
ter of the $R$. solanacearum strain $\left(10^{8}\right.$ $\mathrm{CFU} / \mathrm{ml}$ ) was taken to initiate a 10 -fold dilution series $\left(10^{-1}\right.$ to $\left.10^{-7}\right)$, and $100 \mu \mathrm{l}$ of each dilution was spread on the medium, incubated at $28^{\circ} \mathrm{C}$, and $R$. solanacearum populations were assessed at 48 and $72 \mathrm{~h}$. Plates with Tween 20 but without any oils were used as controls. Each treatment had two replications, and the entire experiment was performed twice.

Epifluorescence microscopy. Live-dead BacLight bacterial viability kit (L7007; Molecular Probes Inc., Eugene, OR) was used for assessing the percentage of live and dead $R$. solanacearum cells after treatment with the oils in a direct contact assay. This method has also been used previously for assessing viability of $R$. solanacearum cells in pathogen survival and disease management studies $(5,24)$. The kit contains Syto9 green fluorescent stain and propidium iodide red fluorescent stain. Syto9 and propidium iodide differ in their spectral characteristics and ability to penetrate bacterial cells. Syto9 stains cells with intact (live) and damaged (dead) membranes. Propidium iodide stains only cells with damaged membranes, causing a reduction in the Syto9 stain fluorescence when both dyes are present. An epifluorescence microscope BX-51 (Olympus America Inc., Melville, NY) fitted with filters U-MWB2 (green and red fluorescence), UMN1B2 (green fluorescence), and UMWG2 (red fluorescence) was used for observation of cells.

The samples for observation using epifluorescence microscopy were prepared by the following direct contact assay. The $R$. solanacearum strain was streaked onto nutrient agar (Difco Laboratories Inc., Detroit, MI) and incubated for $48 \mathrm{~h}$ at $28^{\circ} \mathrm{C}$. Colonies were transferred to sterile $\mathrm{dH}_{2} \mathrm{O}$, vortexed, and adjusted to $\mathrm{OD}_{600 \mathrm{~nm}}=$ $0.1\left(10^{8} \mathrm{CFU} / \mathrm{ml}\right)$. Five hundred microliters of the sample was added to $5.0 \mathrm{ml}$ of nutrient broth in $10-\mathrm{ml}$ test tubes, incubated for $16 \mathrm{~h}$ at $28^{\circ} \mathrm{C}$ in a rotary shaker $(200 \mathrm{rpm})$, and adjusted to an $\mathrm{OD}_{600 \mathrm{~nm}}=$ 0.2 . The oils were added to the test tubes, after emulsifying in Tween 20 , and adjusted to final concentrations of $0.04,0.07$, and $0.14 \% \mathrm{vol} / \mathrm{vol}$. The test tubes were further kept in the shaker for $10 \mathrm{~h}$. One milliliter samples were vortexed and transferred from each tube to a $1.5-\mathrm{ml}$ microfuge tube at 4 and $10 \mathrm{~h}$ after treatment. In addition, $1 \mathrm{ml}$ of untreated cells was pipetted into a microfuge tube and kept in boiling water for $5 \mathrm{~min}$ to heat kill the cells. All of the samples were centrifuged at $16,000 \times g$ for $3 \mathrm{~min}$, and the supernatant was removed. The cells were further washed with sterile $\mathrm{dH}_{2} \mathrm{O}$, resuspended in $0.85 \% \mathrm{NaCl}$, and incubated for $45 \mathrm{~min}$, mixing the sample every $15 \mathrm{~min}$. Syto9 (6 $\mu \mathrm{M})$ and propidium iodide $(30 \mu \mathrm{M})$ at $2 \mu \mathrm{l}$ each per milliliter of the sample were added, pipetted up and down many times to make an even suspension, and kept in the dark for 45 min. Five microliters of the stained bacterial suspension were placed between a glass slide and an 18-mm coverslip before observation of cells with the epifluorescence microscope equipped with the filters as described above. Samples with Tween 20 but without any oils were used as controls. Each treatment had three replications, and the entire experiment was performed three times.

Inoculation of the potting medium. The tested $R$. solanacearum strain was streaked onto a modified TZC medium (12) and incubated for 48 to $72 \mathrm{~h}$ at $28^{\circ} \mathrm{C}$. Typical mucoid white colonies were transferred from TZC to sterile $\mathrm{dH}_{2} \mathrm{O}$, vortexed, and adjusted to $10^{8} \mathrm{CFU} / \mathrm{ml}$. Ten milliliters of the $R$. solanacearum strain was added to pots with 0.25 liters of potting medium (Sunshine Mix 4 Aggregate Plus; Sungro Horticulture Canada Ltd., BC, Canada), 80 $\mathrm{ml}$ into pots with 2 liters of potting medium, and $200 \mathrm{ml}$ into pots with 5 liters of potting medium. The potting medium was evenly mixed with a wooden stick. After 1 $\mathrm{h}, 1 \mathrm{~g}$ of the potting medium was removed and suspended in $10 \mathrm{ml}$ of sterile $\mathrm{dH}_{2} \mathrm{O}$. The samples were vortexed thoroughly for $20 \mathrm{~s}$ and allowed to settle. One milliliter of the supernatant was taken to initiate a 10fold dilution series $\left(10^{-1}\right.$ to $\left.10^{-7}\right)$, and 100 $\mu \mathrm{l}$ of each dilution was plated on modified SMSA medium, incubated for 48 to $72 \mathrm{~h}$ at $28^{\circ} \mathrm{C}$, and $R$. solanacearum populations were assessed (pretreatment).

Treatment application. One hundred microliters of palmarosa and lemongrass oils were emulsified separately in Tween 20 (1:1 ratio), mixed thoroughly in $10 \mathrm{ml}$ of water, and distributed evenly over 0.25 liter of potting medium to give a final concentration of $0.04 \% \mathrm{vol} / \mathrm{vol}$. Similarly, 175 and $350 \mu \mathrm{l}$ of the oils were emulsified in Tween 20 and mixed in $10 \mathrm{ml}$ of water and added for final concentrations of 0.07 and $0.14 \% \mathrm{vol} / \mathrm{vol}$. The emulsion was mixed well and slowly poured into the potting medium. For 2- and 5-liter potting medium, the plant essential oils, Tween 20, and water were proportionately adjusted as described above to achieve final concentrations of $0.04,0.07$, and $0.14 \% \mathrm{vol} / \mathrm{vol}$. The potting medium was evenly mixed, and a transparent vapor barrier plastic cover (4 mil; Carlisle Plastics Inc., Minneapolis, $\mathrm{MN}$ ) was placed on top of the pot, followed by tightly securing it with a plastic wire to prevent escape of volatiles. The duration of the treatment was 7 days, after which the plastic cover was removed, and the pots were left open for 3 days for volatiles to escape. The potting medium was evenly mixed with a clean wooden stick, and 1-g samples were collected and $R$. solanacearum populations assessed (posttreatment).

Controls were kept for each experiment: (i) Control-Tween ( $R$. solanacearum present, no essential oil treatment, only Tween 20 , covered with plastic) to test for the effect of Tween 20; (ii) Control-Cover ( $R$. solanacearum present, no essential oil treatment, no Tween, covered with plastic) to test for the effect of solarization; (iii) Control-No Cover ( $R$. solanacearum present, no essential oil treatment, no Tween, no cover) to compare pathogen survival in essential oil treated and untreated pots; and (iv) Control-No Rs ( $R$. solanacearum not present, no essential oil treatment, no Tween, no cover) to compare growth of the plants under the different treatments and to evaluate possible herbicidal effects.

Evaluation of growth of bioindicator plants and growth and yield of edible ginger. In 0.25-liter pot experiments I and II, and in the 2-liter pot experiment, tissuecultured ginger (chinese type; one plant per pot) was used as a bioindicator to test for the presence of $R$. solanacearum after the treatment (15). Red ginger plantlets were used as bioindicators in 0.25 -liter pot experiment III (15). The bioindicators were planted in test pots 3 days posttreatment and monitored daily for 45 days for symptoms. The pots were hand-watered daily with $10 \mathrm{ml}$ of water in 0.25 -liter pots and $80 \mathrm{ml}$ in 2-liter pots. Three pots per treatment were kept for each 0.25-liter experiment and two pots for the 2-liter pot experiment. In 5-liter pot experiments, edible ginger rhizomes weighing $50 \pm 10 \mathrm{~g}$ (one piece per pot) were planted 7 days after treatment application and monitored daily for 180 days after planting (DAP) for symptoms of bacterial wilt. The plants were watered daily $(200 \mathrm{ml})$ using a drip irrigation system. Three pots per treatment were kept for each 5-liter experiment. Growth characters including average number of tillers/treatment, average height of tillers/treatment, and average number of leaves/tiller/treatment were measured at 30, 60, 90, 120, and 150 DAP. The tillers were removed by 165 DAP, and the irrigation was stopped. The yield of ginger was recorded at 180 DAP, after removal of adhering potting medium and removing roots attached to the rhizome, followed by washing and drying the rhizome for 15 min in sunlight. Presence of $R$. solanacearum in the bioindicator plants and edible ginger was determined by sampling $1 \mathrm{~g}$ of plant tissue $\left(\right.$ ca. $1 \mathrm{~cm}^{3}$ ) excised from the collar region of the infected plant (bioindicators) or from the core of the harvested ginger rhizomes and roots. The plant samples were surface-sterilized with $0.6 \%$ $\mathrm{NaOCl}$ for $2 \mathrm{~min}$, rinsed with sterile $\mathrm{dH}_{2} \mathrm{O}$ twice, and ground with a mortar and pestle in $1 \mathrm{ml}$ of sterile $\mathrm{dH}_{2} \mathrm{O}$. One hundred microliters of BEB1 buffer (Agdia Inc., Elkhart, IN) was added to $100 \mu$ l of the sample extract in a microfuge tube and tested with $R$. solanacearum-specific Immunostrips (Agdia). One-gram potting medium samples were also taken, suspended in $10 \mathrm{ml}$ of $\mathrm{dH}_{2} \mathrm{O}$, vortexed for $20 \mathrm{~s}$, and allowed to settle. One hundred microliters of the supernatant was tested for the presence of $R$. 
solanacearum with Immunostrips by the above-mentioned method. Samples from plant and potting medium were also plated on modified SMSA medium to check for presence of the pathogen.

Experimental design and statistical analysis. All in vitro studies were set up in a completely randomized design, and the pot tests were conducted as a randomized complete block experiment. The data were analyzed using ANOVA, and the means were compared using Student-NewmanKeuls test $(P \geq 0.05)$. The analysis was performed with SAS (SAS version 9.1, SAS Institute Inc., Cary, NC).

\section{RESULTS}

In vitro: Culture amendment assay. $R$. solanacearum did not grow on plates amended with palmarosa oil at any concentration or lemongrass oil at 0.07 and $0.14 \%$ (Fig. 1) at $48 \mathrm{~h}$ after incubation. At $72 \mathrm{~h}$, growth was seen on plates amended with palmarosa oil at $0.04 \%$, but the populations were at ca. $2 \log \left(10^{2}\right) \mathrm{CFU} / \mathrm{ml}$, significantly lower than the control with ca. $8 \log \mathrm{CFU} / \mathrm{ml}$. At $48 \mathrm{~h}, R$. solanacearum growth was significantly lower on plates amended with lemongrass oil at $0.04 \%$ (ca. $3 \log \mathrm{CFU} / \mathrm{ml}$ ) than on controls (ca. $8 \log \mathrm{CFU} / \mathrm{ml}$ ). However, new $R$. solanacearum colonies formed at $72 \mathrm{~h}$, increasing the population levels to ca. $4 \log$ $\mathrm{CFU} / \mathrm{ml}$. There was no change in the growth after $72 \mathrm{~h}$, as indicated by the absence of any new colonies in any of the treatments (data not shown). Eucalyptus oil did not significantly prevent growth of $R$. solanacearum at any concentration except at $0.14 \%$ at $48 \mathrm{~h}$.

Percentage of live and dead cells evaluated by epifluorescence microscopy. In the untreated $R$. solanacearum control, ca. $95 \%$ of the cells stained green, indicating a high percentage of live cells at 4 and $10 \mathrm{~h}$ after treatment (Fig. 2A). In heat-killed $R$. solanacearum cells, $100 \%$ of the cells stained red, indicating dead cells. $R$. solanacearum cells treated with eucalyptus oil at 0.04 and $0.07 \%$ showed ca. 85 and $80 \%$ live cells, respectively, at $4 \mathrm{~h}$ after treatment (Fig. 2B). At $10 \mathrm{~h}$ after treatment, this proportion increased to $>95 \%$ live cells at both concentrations of eucalyptus oil (Fig. 2B). This suggests that cells treated with the oil at 0.04 and $0.07 \%$ continued to multiply and formed new cells between 4 and $10 \mathrm{~h}$ after treatments. However, the numbers of live cells were much lower after treatment with eucalyptus oil at $0.07 \%$ (Fig. 2B). Lemongrass and palmarosa oil at all concentrations and eucalyptus oil at $0.14 \%$ resulted in the death of more than $95 \%$ of cells (stained red) (Fig. 2A and B). In addition, the numbers of cells observed in these treatments were significantly lower compared to those observed in the untreated (control) and heat-killed cells. Large masses of cellular debris were observed (picture not shown) in palmarosa and lemongrass oils at all concentrations and eucalyptus oil at $0.14 \%$, suggesting that cells completely ruptured due to the treatments. Although these represented dead cells, they could not be counted individually.

Pathogen survival in potting medium treated with oils. Palmarosa and lemongrass oils were the most effective in the in vitro and epifluorescence microscopic studies, so these were selected for further pot studies. $R$. solanacearum populations in potting medium at pretreatment were ca. 6 to $7 \log$ CFU/g. In 0.25 -liter pot studies, the pathogen did not survive in potting medium treated with palmarosa oil at any concentration or with lemongrass oil at $0.07 \%$ (Fig. 3). Control-Tween and Control-Cover were ca. 2 log units below the populations in the Control-No Cover pots, indicating a partial effect of Tween and/or heat in suppressing $R$. solanacearum populations.

In the 2-liter pot experiment, the pathogen did not survive when $R$. solanacearum-infested potting medium was treated with palmarosa and lemongrass oils at 0.07 and $0.14 \%$ (Fig. 4A), whereas it survived at high levels (ca. 5 log CFU/g) when treated with these oils at $0.04 \%$. However, the pathogen populations in the $0.04 \%$ treatments were not significantly lower than the Control-Cover or the ControlTween, showing again that Tween alone and heat have an effect on population reduction. In 5-liter pot experiment I, the pathogen did not survive in any of the pots treated with palmarosa or lemongrass oils at any concentration (Fig. 4B). The pathogen survived in Control-Tween and Control-Cover pots, but the populations were significantly lower than in Control-No cover pots. Survival of the pathogen in 5liter pot experiment II was similar to that in 5-liter pot experiment I (Fig. 4C).

Disease control in $R$. solanacearuminfested potting medium treated with essential oils. In 0.25-liter pot tests, all the bioindicator plants remained healthy and showed no disease symptoms in infested potting medium treated with palmarosa oil at all concentrations and lemongrass oil at $0.07 \%$ (Table 1). Only two of the nine bioindicator plants wilted during the experiments when planted in potting medium treated with lemongrass oil at $0.04 \%$. All the plants in the Control-Tween, ControlCover, and Control-No cover wilted within

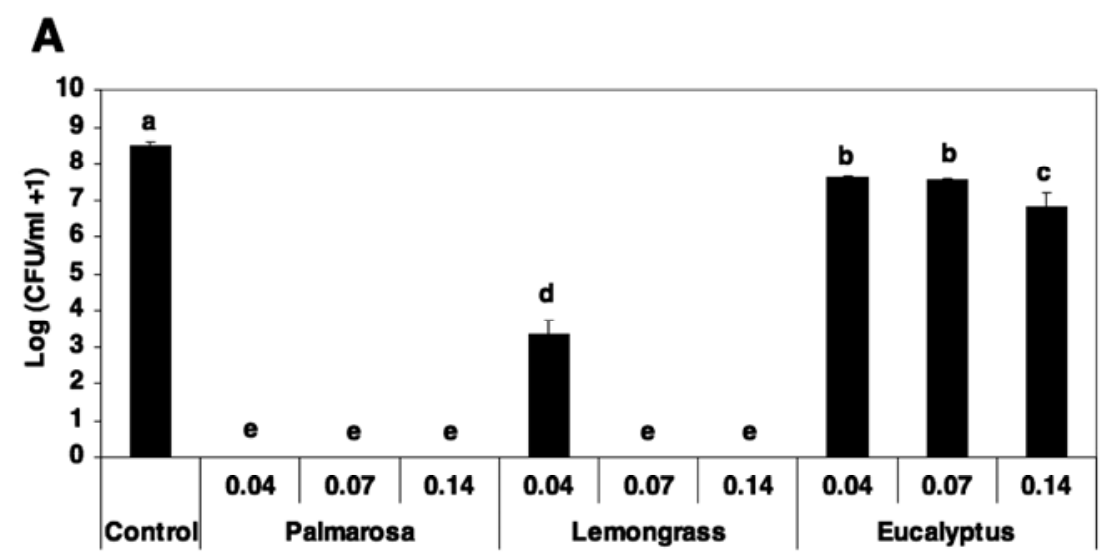

\section{B}

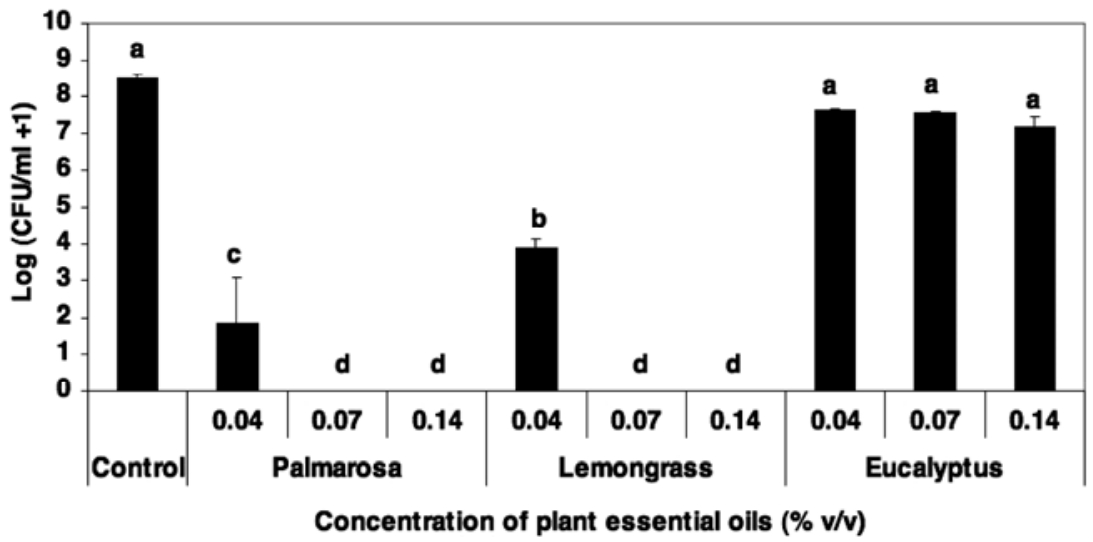

Fig. 1. Effect of essential plant oils on growth of Ralstonia solanacearum race 4 strain A4515 in culture. A, Growth after $48 \mathrm{~h}$ incubation; B, growth after $72 \mathrm{~h}$ incubation. Means $(n=4)$ with the same letters are not significantly different $(P \leq 0.05)$ based on Student-Newman-Keuls test. Error bars indicate standard error of mean. 


\section{Control}
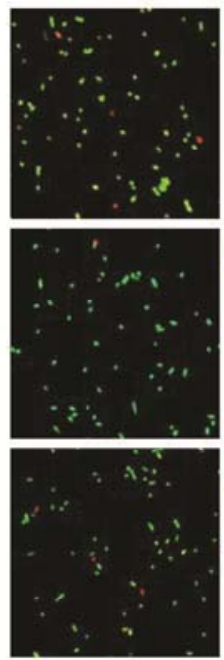

\subsection{4}

0.07
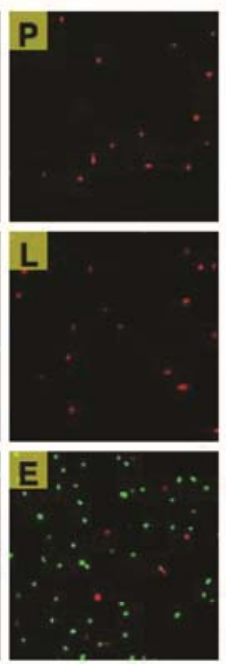
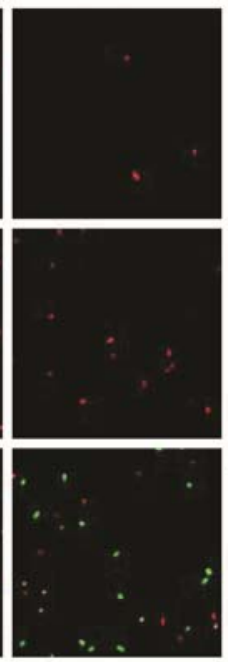

0.14
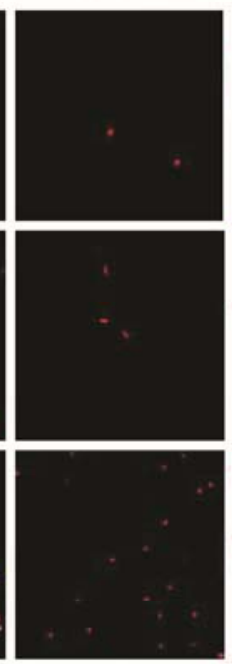

\section{Heat killed}
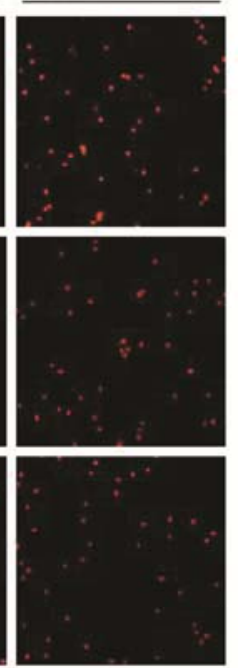

B

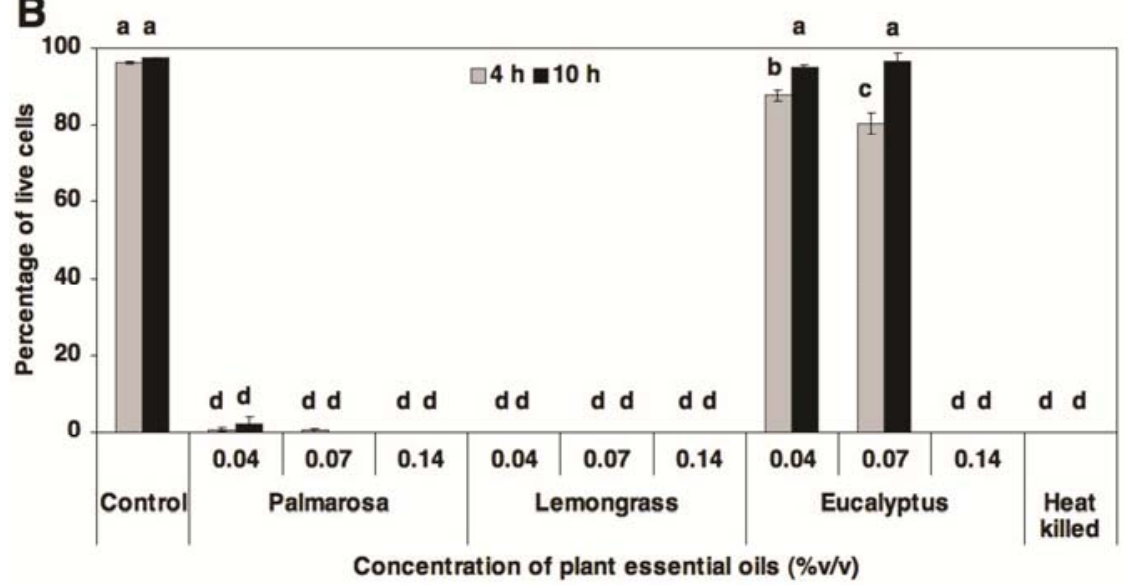

Fig. 2. Ralstonia solanacearum race 4 strain A4515 observed by epifluorescence microscopy after treatment with palmarosa (P), lemongrass (L), and eucalyptus (E) oils. A, Green and red stained cells indicate live and dead cells, respectively. B, Percentage of live cells 4 and $10 \mathrm{~h}$ after treatment with palmarosa, lemongrass, and eucalyptus oils. Means $(n=24)$ with the same letter are not significantly different $(P \leq 0.05)$ based on Student-Newman-Keuls test. Error bars indicate standard error of mean.

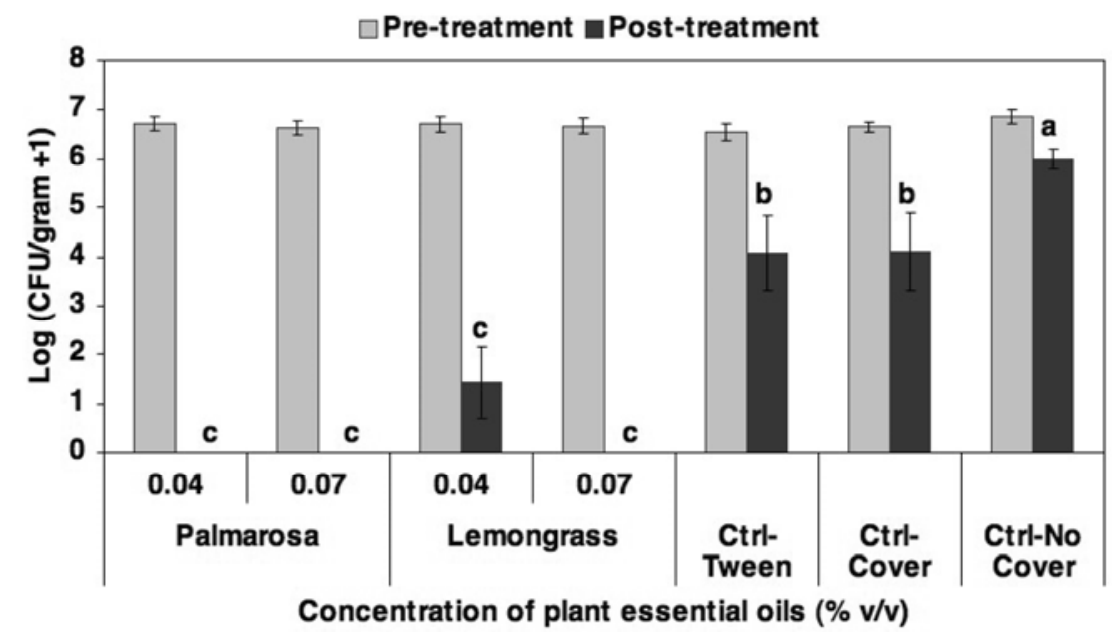

Fig. 3. Survival of Ralstonia solanacearum race 4 strain A4515 in potting medium after treatment with palmarosa and lemongrass oils in 0.25 -liter pots. Means $(n=9)$ with the same letter are not significantly different $(P \leq 0.05)$ based on Student-Newman-Keuls test. Error bars indicate standard error of mean.
45 days. The plant samples from wilted plants tested positive with $R$. solanacearum-specific immunostrips, confirming the cause of the wilt. All the plants in Control-No Rs remained healthy throughout the experimental period.

In the 2-liter pot experiments, all the tissue-cultured plants in potting medium treated with palmarosa and lemongrass oil at 0.07 and $0.14 \%$ survived (Table 1), whereas all the plants in the palmarosa and lemongrass oil treatments at $0.04 \%$, Control-Tween, Control-Cover, and ControlNo cover, wilted. The plants in Control-No Rs remained healthy. In 5-liter pot experiment I, all edible ginger plants in potting medium treated with palmarosa and lemongrass oils at all concentrations remained healthy throughout the period of the experiment (Table 1). All the controls with the pathogen wilted and plants in ControlNo Rs remained healthy until 180 DAP. Similar results were obtained in 5-liter pot experiment II (Table 1). However, one plant in the potting medium treated with palmarosa oil at $0.04 \%$ wilted. Interestingly, one plant in Control-Cover did not wilt during the entire period of the experiment, even though the pathogen survived in that pot after treatment application. The potting medium and plant samples in pots with healthy plants gave negative results by culturing and immunostrips, and no latent infections were detected by either method. The pathogen did not survive in these pots as indicated by absence of growth on modified SMSA medium.

Growth and yield of edible ginger planted in $R$. solanacearum-infested potting medium treated with essential oils. In 5-liter pot experiment I, no significant variations were noted in the average number of tillers of edible ginger due to the treatments in comparison with plants in Control-No Rs at 150 DAP (Table 2). However, in the preliminary phase of growth (90 DAP), plants in potting medium treated with palmarosa oil at $0.14 \%$ showed higher numbers of tillers compared with those in other essential oil treatments (data not shown). In 5-liter pot experiment II, no significant differences in the average number of tillers between plants in essential oil treated pots and Control-No Rs were noted at 150 DAP (Table 2). Assessment of average height of the tillers/treatment showed no significant differences between plants in essential oil treated pots and Control-No Rs in either of the experiments (Table 2). The average number of leaves/tiller/treatment data taken from the essential oil treatments in both experiments were not significantly different from the Control-No Rs treatments (Table 2). None of the plant essential oil treatments caused any reduction in the yield of ginger in the experiments (Table 3), whereas all of the plants in the control pots were killed except for one plant in Control-Cover treatment. 


\section{DISCUSSION}

The United States is the world's largest consumer of methyl bromide, where this chemical is being used mainly for preplanting fumigation of tomato, strawberry, pepper, ginger, and other vegetable crops for the management of diverse plant pathogenic organisms including $R$. solanacearum $(21,22)$. Since methyl bromide is currently restricted for field use, plant essential oils were evaluated as alternative biofumigants in this study. Our studies based on a culture amendment assay showed the bactericidal properties of palmarosa and lemongrass oils and bacteriostatic properties of eucalyptus oil on $R$. solanacearum race 4 , which confirms our earlier results using disk, well, and vapor diffusion assays (14). Epifluorescence microscopy using Syto9 and propidium iodide also confirmed the bactericidal properties of palmarosa and lemongrass oils. Scanning and transmission electron micrographs showed distortion and rupture of cell wall following treatment with these oils (14).

No bacteria were recovered from any of the essential oil treatments of infested potting medium in both of the 5-liter pot tests. All plants stayed healthy in these treatments except one plant in potting medium treated with palmarosa oil at $0.04 \%$ (experiment II). In this case, the pathogen may have survived at very low levels in the potting medium, making it undetectable by culturing. However, presence of a plant may have significantly increased the pathogen populations, leading to infection at a later stage of growth. In the same experiment, one of the plants in the Control-Cover pot did not wilt even after planting in the presence of the pathogen. This plant was not infected, as indicated by immunostrip assays and culturing at the end of the experiment. The pathogen did not survive in this pot at the end of the experiment, and this may be due to the failure of the pathogen to enter plant roots; hence, populations dropped below detectable levels. All the pot studies have shown the bactericidal effects of palmarosa and lemongrass oils as indicated by significant reductions in live $R$. solanacearum populations.

None of the essential oil treatments reduced the growth and yield of ginger at the tested concentrations. Edible ginger is an 8- to 10-month crop with a 2- to 4month fallow period between harvest and new planting. The pathogen can survive in plant debris for 3 to 5 months under ideal conditions and can infect the new crop (16). Our findings that palmarosa and lemongrass oils greatly reduce $R$. solanacearum in potting medium within 7 days suggests that they could be used under field conditions without a long waiting period between treatment and planting.
A hindrance to field application of these oils currently is the exorbitant price of these oils in the U.S. market. This is due to the limited production of these crops in the United States, leading to the import of oils from other countries. Thus, large-scale application of these oils to treat $R$. solanacearum-infested fields in the United States may not be presently practical considering that even at a $0.04 \%$ concentration, $100 \mathrm{ml}$ of the essential oil would be needed to treat one square meter to a $25-\mathrm{cm}$ depth.
However, if the essential oils are used in a small area, rapid spread of the disease from field to field from a single point of infection could be effectively prevented in a very short time, thereby saving the bulk of the crop from infection.

Cover cropping followed by mulching of crops in order to release volatiles of essential oils into pathogen-infested fields is also an interesting approach. This strategy has been studied on a $R$. solanacearum-infested plot using Brassica spp. as
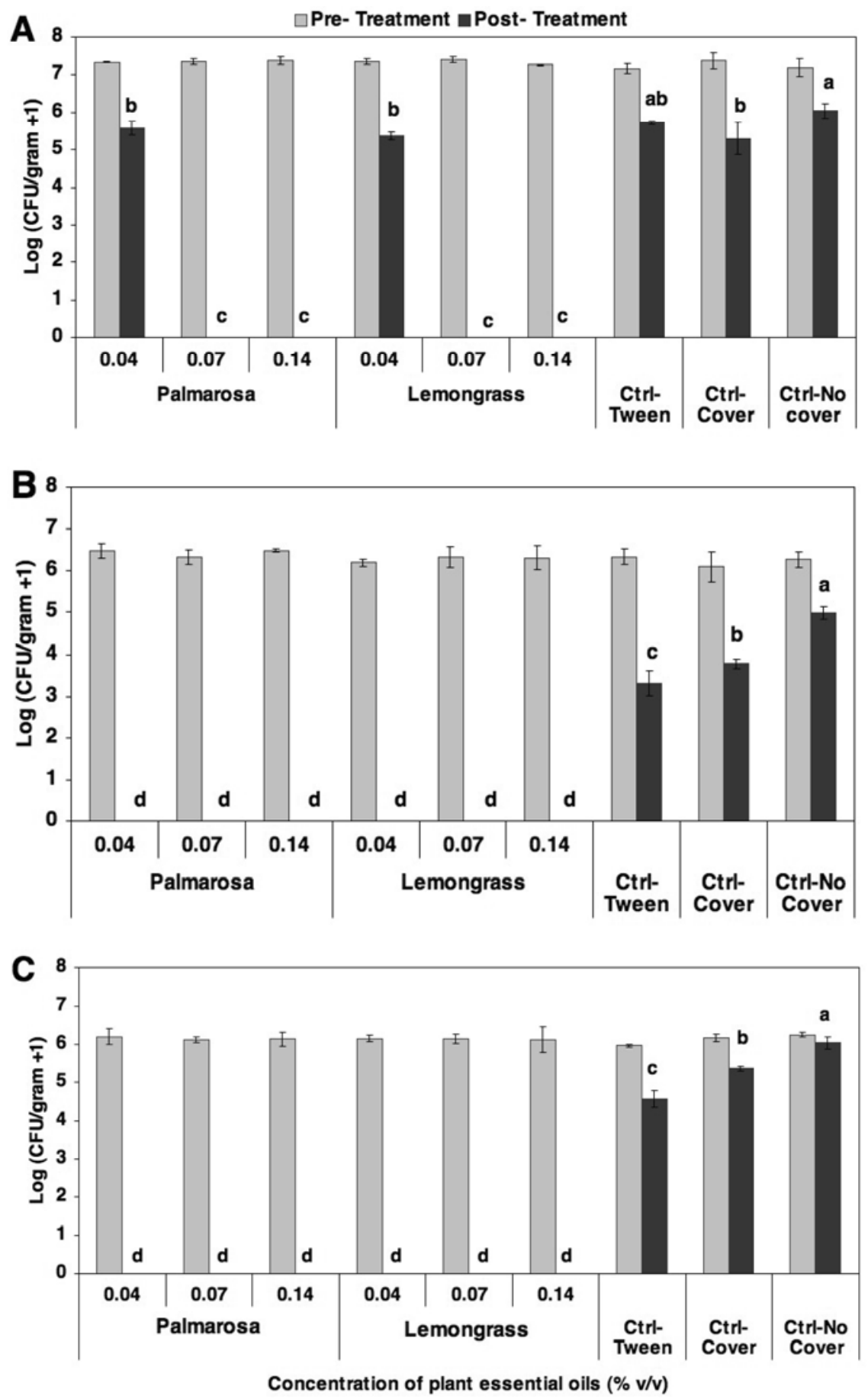

Fig. 4. Survival of Ralstonia solanacearum race 4 strain A4515 in potting medium after treatment with palmarosa and lemongrass oils. A, 2-liter pots $(n=2) ; \mathbf{B}, 5$-liter pot experiment I $(n=3) ; \mathbf{C}, 5$-liter pot experiment II $(n=3)$. Means with the same letter are not significantly different $(P \leq 0.05)$ based on Student-Newman-Keuls test. Error bars indicate standard error of mean. 
Table 1. Number of plants wilted in Ralstonia solanacearum-infested potting medium treated with plant essential oils in 0.25-, 2-, and 5-liter pots

\begin{tabular}{|c|c|c|c|c|c|c|c|}
\hline \multirow[b]{3}{*}{ Treatment } & \multirow[b]{3}{*}{ Conc. $\% \mathrm{v} / \mathbf{v}^{\mathbf{r}}$} & \multicolumn{6}{|c|}{ Number of plants wilted ${ }^{q}$} \\
\hline & & \multicolumn{3}{|c|}{0.25 -liter pots } & \multirow{2}{*}{$\begin{array}{c}\text { 2-liter pots } \\
\text { Exp. Is }\end{array}$} & \multicolumn{2}{|c|}{ 5-liter pots } \\
\hline & & Exp. Is & Exp. IIs & Exp. III ${ }^{t}$ & & Exp. I ${ }^{\mathbf{u}}$ & Exp. II ${ }^{\mathbf{u}}$ \\
\hline \multirow[t]{3}{*}{ Palmarosa oil ${ }^{\mathrm{v}}$} & 0.04 & 0 & 0 & 0 & 2 & 0 & 1 \\
\hline & 0.07 & 0 & 0 & 0 & 0 & 0 & 0 \\
\hline & 0.14 & $\ldots$ & $\ldots$ & $\ldots$ & 0 & 0 & 0 \\
\hline \multirow[t]{3}{*}{ Lemongrass oil ${ }^{\mathrm{v}}$} & 0.04 & 1 & 1 & 0 & 2 & 0 & 0 \\
\hline & 0.07 & 0 & 0 & 0 & 0 & 0 & 0 \\
\hline & 0.14 & $\ldots$ & $\ldots$ & $\ldots$ & 0 & 0 & 0 \\
\hline Ctrl-Tween ${ }^{w}$ & $\ldots$ & 3 & 3 & 3 & 2 & 3 & 3 \\
\hline Ctrl-Cover ${ }^{\mathrm{X}}$ & $\ldots$ & 3 & 3 & 3 & 2 & 3 & 2 \\
\hline Ctrl-No cover ${ }^{\mathrm{y}}$ & $\ldots$ & 3 & 3 & 3 & 2 & 3 & 3 \\
\hline Ctrl-No Rs ${ }^{z}$ & $\ldots$ & 0 & 0 & 0 & 0 & 0 & 0 \\
\hline
\end{tabular}

q Three plants were tested in each experiment except the 2-liter experiment, which had two plants.

$\mathrm{r} \% \mathrm{v} / \mathrm{v}$ represents concentration in volume/volume.

$s$ Tissue-cultured ginger plants (0.25/2-liter pots) were used as bioindicators for $R$. solanacearum, and plants were monitored for 45 days.

${ }^{\mathrm{t}}$ Micro-sized red ginger plants (0.25-liter pots) were used as bioindicators for $R$. solanacearum, and plants were monitored for 45 days.

${ }^{u}$ Edible ginger rhizomes were planted (5-liter pots) and monitored for 180 days.

${ }^{v}$ Essential oils were emulsified in Tween 20 (1:1 ratio) and mixed in water. Emulsion was poured and mixed in $R$. solanacearum-infested potting medium.

Pots were covered with a transparent plastic cover for 7 days.

${ }^{\mathrm{w}}$ Control-Tween: Pathogen present, no essential oil treatment (only Tween 20), covered with plastic.

x Control-Cover: Pathogen present, no essential oil treatment, no Tween, covered with plastic.

y Control-No cover: Pathogen present, no essential oil treatment, no Tween, no cover.

${ }^{\mathrm{z}}$ Control-No Rs: No pathogen, no essential oil treatment, no Tween, no cover.

Table 2. Growth of edible ginger planted in 5 liters of potting medium infested with Ralstonia solanacearum race 4 strain A4515 and treated with plant essential oils. Data were recorded 150 days after planting (DAP)

\begin{tabular}{|c|c|c|c|c|c|c|c|}
\hline \multirow[b]{3}{*}{ Treatment } & \multirow[b]{3}{*}{ Conc. $\% \mathrm{v} / \mathbf{v}^{\mathrm{t}}$} & \multicolumn{6}{|c|}{ Growth of edible ginger at 150 DAP } \\
\hline & & \multicolumn{2}{|c|}{ Average no. tillers/treatment } & \multicolumn{2}{|c|}{ Average height tillers/treatment $(\mathrm{cm})$} & \multicolumn{2}{|c|}{ Average no. leaves/tiller/treatment } \\
\hline & & Exp. I & Exp. II & Exp. I & Exp. II & Exp. I & Exp. II \\
\hline \multirow[t]{3}{*}{ Palmarosa oil ${ }^{\mathrm{u}}$} & 0.04 & $2.3 \mathrm{a}^{\mathrm{v}}$ & $1.0 \mathrm{ab}$ & $68.2 \mathrm{a}$ & $43.3 \mathrm{ab}$ & $21.0 \mathrm{a}$ & $15.8 \mathrm{ab}$ \\
\hline & 0.07 & $4.3 \mathrm{a}$ & $1.7 \mathrm{ab}$ & $48.8 \mathrm{a}$ & $65.5 \mathrm{a}$ & $16.9 \mathrm{a}$ & $22.7 \mathrm{a}$ \\
\hline & 0.14 & $4.0 \mathrm{a}$ & $1.7 \mathrm{ab}$ & $55.3 \mathrm{a}$ & $66.9 \mathrm{a}$ & $18.7 \mathrm{a}$ & $22.2 \mathrm{a}$ \\
\hline \multirow[t]{3}{*}{ Lemongrass oil $^{\mathrm{u}}$} & 0.04 & $3.3 \mathrm{a}$ & $2.3 \mathrm{ab}$ & $37.0 \mathrm{ab}$ & $55.1 \mathrm{ab}$ & $14.1 \mathrm{a}$ & $17.7 \mathrm{ab}$ \\
\hline & 0.07 & $3.0 \mathrm{a}$ & $3.7 \mathrm{a}$ & $37.2 \mathrm{ab}$ & $49.6 \mathrm{ab}$ & $13.5 \mathrm{a}$ & $17.6 \mathrm{ab}$ \\
\hline & 0.14 & $4.7 \mathrm{a}$ & $1.7 \mathrm{ab}$ & $49.1 \mathrm{a}$ & $56.2 \mathrm{ab}$ & $15.8 \mathrm{a}$ & $19.1 \mathrm{a}$ \\
\hline Control-Tween ${ }^{\mathrm{w}}$ & $\ldots$ & $0.0 \mathrm{a}$ & $0.0 \mathrm{~b}$ & $0.0 \mathrm{~b}$ & $0.0 \mathrm{c}$ & $0.0 \mathrm{a}$ & $0.0 \mathrm{~b}$ \\
\hline Control-Cover ${ }^{\mathrm{x}}$ & $\ldots$ & $0.0 \mathrm{a}$ & $1.0 \mathrm{ab}$ & $0.0 \mathrm{~b}$ & $15.4 \mathrm{bc}$ & $0.0 \mathrm{a}$ & $4.8 \mathrm{ab}$ \\
\hline Control-No cover ${ }^{\mathrm{y}}$ & $\ldots$ & $0.0 \mathrm{a}$ & $0.0 \mathrm{~b}$ & $0.0 \mathrm{~b}$ & $0.0 \mathrm{c}$ & $0.0 \mathrm{a}$ & $0.0 \mathrm{~b}$ \\
\hline Control-No Rs ${ }^{\mathrm{z}}$ & $\ldots$ & $2.0 \mathrm{a}$ & $3.3 \mathrm{ab}$ & $52.1 \mathrm{a}$ & $48.9 \mathrm{ab}$ & $17.9 \mathrm{a}$ & $17.4 \mathrm{ab}$ \\
\hline
\end{tabular}

$\mathrm{t} \% \mathrm{v} / \mathrm{v}$ represents concentration in volume/volume.

" Essential oils were emulsified in Tween 20 (1:1 ratio) and mixed in water. Emulsion was poured and mixed in $R$. solanacearum-infested potting medium.

Pots were covered with a transparent plastic cover for 7 days. Edible ginger was planted 7 days after the treatment.

${ }^{v}$ Column means ( 3 reps per treatment) indicated with the same letters are not significantly different $(P \leq 0.05)$ based on Student-Newman-Keuls test.

${ }^{w}$ Control-Tween: Pathogen present, no essential oil treatment (only Tween 20), covered with plastic.

${ }^{x}$ Control-Cover: Pathogen present, no essential oil treatment, no Tween, covered with plastic.

y Control-No cover: Pathogen present, no essential oil treatment, no Tween, no cover.

${ }^{\mathrm{z}}$ Control-No Rs: No pathogen, no essential oil treatment, no Tween, no cover.

cover crops (2). This plant genus has high glucosinolates during flowering, and upon mulching of the plant into the soil it hydrolyses to antimicrobial isothiocyanates, nitriles, or thiocyanates, thereby reducing $R$. solanacearum populations. Further research needs to be initiated to study the effect of growing palmarosa and lemongrass plants followed by mulching into field soil on $R$. solanacearum populations. Freshly harvested leaves of thyme (Thymus vulgaris) and oregano (Origanum vulgare) were previously studied, but there was no reduction in the incidence of bacterial wilt on tomato, although thyme oil itself reduced disease incidence (18). A possible reason for this is that the fresh leaves did not have enough essential oil components to suppress the bacterial populations (18).
Another reason might have been that soil temperatures were too low for release of the volatile components of the oils. Therefore, tarping the cover crop followed by mulching of the plants into the soil may enhance the effects of soil amendments with fresh leaves, and this approach needs to be evaluated.

Another approach in reducing the cost of application is to determine the active ingredients of these oils and to synthesize them. For example, a volatile compound, thymol, from Thymus spp. has been used to reduce bacterial wilt of tomato in Florida $(9,10,18,19)$. These studies have shown that synthetically produced agricultural grade thymol is economically feasible. In combination with acibenzolar-S-methyl, an inducer of systemic acquired resistance, thymol significantly reduced bacterial wilt and root-knot nematode infections of tomato in field studies $(10,19)$.

Our studies using essential oils from palmarosa and lemongrass have shown that these oils inhibit $R$. solanacearum race 4 strain in vitro and in potting medium, and they reduced disease incidence and severity in greenhouse tests. These plant essential oils might therefore be effectively used to treat edible ginger fields with previous history of bacterial wilt disease. The biorationale approach of using plant essential oils for control of bacterial wilt disease thus may hold the key for further development and identification of other natural substances for integrated disease management. 
Table 3. Average yield of edible ginger/treatment (grams) in 5-liter pot experiments ${ }^{\mathrm{s}}$

\begin{tabular}{|c|c|c|c|}
\hline \multirow[b]{3}{*}{ Treatment } & \multirow[b]{3}{*}{ Conc. $\% v / v^{t}$} & \multicolumn{2}{|c|}{ Yield (g) } \\
\hline & & \multicolumn{2}{|c|}{ 5-liter pots } \\
\hline & & Exp. I & Exp. II \\
\hline \multirow[t]{3}{*}{ Palmarosa oil ${ }^{\mathrm{u}}$} & 0.04 & $190.7 \mathrm{a}^{\mathrm{v}}$ & $169.3 \mathrm{ab}$ \\
\hline & 0.07 & $167.3 \mathrm{a}$ & $149.3 \mathrm{ab}$ \\
\hline & 0.14 & $222.3 \mathrm{a}$ & $86.0 \mathrm{abc}$ \\
\hline \multirow[t]{3}{*}{ Lemongrass oil ${ }^{\mathrm{u}}$} & 0.04 & $157.0 \mathrm{a}$ & $185.7 \mathrm{ab}$ \\
\hline & 0.07 & $164.0 \mathrm{a}$ & $193.7 \mathrm{ab}$ \\
\hline & 0.14 & $180.0 \mathrm{a}$ & $205.7 \mathrm{a}$ \\
\hline Control-Tween ${ }^{w}$ & $\ldots$ & $0.0 \mathrm{~b}$ & $0.0 \mathrm{c}$ \\
\hline Control-Cover ${ }^{\mathrm{x}}$ & $\ldots$ & $0.0 \mathrm{~b}$ & $47.3 \mathrm{bc}$ \\
\hline Control-No cover ${ }^{\mathrm{y}}$ & $\ldots$ & $0.0 \mathrm{~b}$ & $0.0 \mathrm{c}$ \\
\hline Control-No Rs ${ }^{\mathrm{z}}$ & $\ldots$ & $168.3 \mathrm{a}$ & $227.3 \mathrm{a}$ \\
\hline
\end{tabular}

${ }^{\mathrm{s}}$ Edible ginger was planted in potting medium infested with Ralstonia solanacearum race 4 strain A4515 and treated with plant essential oils; yield was evaluated at 180 days after planting.

$\mathrm{t} \% \mathrm{v} / \mathrm{v}$ represents concentration in volume/volume.

${ }^{\mathrm{u}}$ Essential oils were emulsified in Tween 20 (1:1 ratio) and mixed in water. Emulsion was poured and mixed in $R$. solanacearum-infested potting medium. Pots were covered with a transparent plastic cover for 7 days. Edible ginger was planted 7 days after treatment.

${ }^{v}$ Column means ( 3 reps per treatment) indicated with the same letters are not significantly different $(P$ $\leq 0.05$ ) based on Student-Newman-Keuls test.

${ }^{\mathrm{w}}$ Control-Tween: Pathogen present, no essential oil treatment (only Tween 20), covered with plastic.

${ }^{x}$ Control-Cover: Pathogen present, no essential oil treatment, no Tween, covered with plastic.

${ }^{y}$ Control-No cover: Pathogen present, no essential oil treatment, no Tween, no cover.

${ }^{\mathrm{z}}$ Control-No Rs: No pathogen, no essential oil treatment, no Tween, no cover.

\section{ACKNOWLEDGMENTS}

We gratefully acknowledge the technical assistance of Tina Carvalho at the University of Hawaii, Biological Electron Microscope Facility. The project was partially funded by USDA Special Grants program for Tropical and Subtropical Agricultural Research (Award No. 2004-34135-15191) and USDA-ARS/Minor Crops Research (Award No. 595320-1-525).

\section{LITERATURE CITED}

1. Alvarez, A. M., Trotter, K. J., Swafford, M. B., Berestecky, J. M., Yu, Q., Ming, R., Hepperly, P. R., and Zee, F. 2005. Characterization and detection of Ralstonia solanacearum strains causing bacterial wilt of ginger in Hawaii. In: Bacterial Wilt Disease and the Ralstonia solanacearum Species Complex. C. Allen, P. Prior, and A. C. Hayward, eds. American Phytopathological Society, St. Paul, MN.

2. Arthy, J. R., Akiew, E. B., Kirkegaard, J. A., and Trevorrow, P. R. 2005. Using Brassica spp. as bio-fumigants to reduce the population of Ralstonia solanacearum. In: Bacterial Wilt Disease and the Ralstonia solanacearum Species Complex. C. Allen, P. Prior, and A. C. Hayward, eds. American Phytopathological Society, St. Paul, MN.

3. Bowers, J. H., and Locke, J. C. 2004. Effect of formulated plant extracts and oils on population density of Phytophthora nicotianae in soil and control of Phytophthora blight in the greenhouse. Plant Dis. 88:11-16.

4. Engelbrecht, M. C. 1994. Modification of a semi-selective medium for the isolation and quantification of Pseudomonas solanacearum. ACIAR Bacterial Wilt Newsl. 10:3-5.

5. Grey, B. E., and Steck, T. R. 2001. The viable but non-culturable state of Ralstonia solana- cearum may be involved in long-term survival and plant infection. Appl. Environ. Microbiol. 67:3866-3872

6. Hayward, A. C. 1991. Biology and epidemiology of bacterial wilt caused by Pseudomonas solanacearum. Annu. Rev. Phytopathol. 29:6587.

7. Hepperly, P., Zee, F., Kai, R., Arakawa, C., Meisner, M., Kratky, B., Hamamoto, K., and Sato, D. 2004. Producing bacterial wilt-free ginger in greenhouse culture. Cooperative Exture and Human Resources, University of Hawaii at Manoa. SCM-8:1-6. caused by Pseudomonas solanacearum E. F. Smith. Plant Dis. Rep. 47:710-713.

9. Ji, P., Momol, M. T., Olson, S. M., Pradhanang, P. M., and Jones, J. B. 2005. Evaluation of thymol as biofumigant for control of bacterial wilt of tomato under field conditions. Plant Dis. 89:497-500.

10. Ji, P., Momol, M. T., Rich, J. R., Olson, S. M., and Jones, J. B. 2007. Development of an integrated approach for managing bacterial wilt and root-knot on tomato under field conditions. Plant Dis. 91:1321-1326.

11. Kishore, G. K., Pande, S., and Harish, S. 2007. Evaluation of essential oils and their components for broad-spectrum antifungal activity and control of late leaf spot and crown rot diseases in peanut. Plant Dis. 91:375-379.

12. Norman, D. J., and Alvarez, A. M. 1989. A rapid method for presumptive identification of Xanthomonas campestris pv. dieffenbachiae and other xanthomonads. Plant Dis. 73:654658.

13. Oka, Y., Nacar, S., Putievsky, E., Ravid, U., Yaniv, Z., and Spiegel, Y. 2000. Nematicidal tension Service, College of Tropical Agricul-

8. Ishii, M., and Aragaki, M. 1963. Ginger wilt activity of essential oils and their components against the root-knot nematode. Phytopathology 90:710-715.

14. Paret, M. L. 2009. Management of bacterial wilt of ginger (Zingiber officinale R.) caused by Ralstonia solanacearum with plant essential oils. Ph.D. diss. Department of Plant and Environmental Protection Sciences, College of Tropical Agriculture and Human Resources, University of Hawaii at Manoa, Honolulu, HI.

15. Paret, M. L., deSilva, A. S., and Alvarez, A. M. 2009. Bioindicators for Ralstonia solanacearum race 4: Plants in the Zingiberaceae and Costaceae families. Aust. Plant Pathol. 38:612.

16. Paret, M. L., deSilva, A. S., Criley, R. A., and Alvarez, A. M. 2008. Ralstonia solanacearum race 4: Risk assessment for edible ginger and floricultural ginger industries in Hawaii. HortTechnol. 18:90-96.

17. Perez, E. E., and Lewis, E. E. 2006. Use of entomopathogenic nematodes and thyme oil to suppress plant-parasitic nematodes on English boxwood. Plant Dis. 90:471-475.

18. Pradhanang, P. M., Momol, M. T., Olson, S. M., and Jones, J. B. 2003. Effects of plant essential oils on Ralstonia solanacearum population density and bacterial wilt incidence in tomato. Plant Dis. 87:423-427.

19. Pradhanang, P. M., Momol, M. T., Olson, S. M., and Jones, J. B. 2005. Management of bacterial wilt in tomato with essential oils and systemic acquired resistance inducers. In: Bacterial Wilt Disease and the Ralstonia solanacearum Species Complex. C. Allen, P. Prior, and A. C. Hayward, eds. American Phytopathological Society, St. Paul, MN.

20. Reitz, S. R., Maiorino, G., Olson, S., Sprenkel, R., Crescenzi, A., and Momol, M. T. 2008. Integrating plant essential oils and kaolin for the sustainable management of thrips and tomato spotted wilt on tomato. Plant Dis. 92:878-886.

21. Rosskopf, E. N., Chellemi, D. O., KokalisBurelle, N., and Church, G. T. 2005. Alternatives to methyl bromide: A Florida perspective. APSnet feature story June 2005. Online publication.

22. Sato, D. 1999. Reducing methyl bromide in pre-plant soil treatment for ginger root. Annu. Int. Res. Conf. Methyl Bromide Alternatives Emissions Reductions. San Diego, CA. Online publication.

23. Shintaku, M., Seeve, C., and Shimabukuro, A. 2006. PCR assay of the rhizosphere soil of weeds associated with an outbreak of bacterial wilt of ginger in east Hawaii. J. Hawaiian Pacific Agric. 13:9-14

24. van der Wolf, J. M., Sledz, V., Elsas, J. D. v., Overbeek, L. v., and Bergervoet, J. H. W. 2005. Flow cytometry to detect Ralstonia solanacearum and to assess viability. In: Bacterial Wilt Disease and the Ralstonia solanacearum Species Complex. C. Allen, P. Prior, and A. C. Hayward, eds. American Phytopathological Society, St.Paul, MN.

25. Yu, Q., Alvarez, A. M., Moore, P. H., Zee, F., Kim, M. S., de Silva, A. S., Hepperly, P. R., and Ming, R. 2003. Molecular diversity of Ralstonia solanacearum isolated from ginger in Hawaii. Phytopathology 93:1124-1130. 